\title{
Overview of Problems Associated with Ineffective Enforcement of Market Abuse Provisions in South Africa
}

\author{
Howard Chitimira \\ Lecturer, Faculty of Law, North-West University \\ E-mail: Howard.Chitimira@nwu.ac.za, tafarachitimira@gmail.com
}

Doi:10.5901/mjss.2014.v5n4p47

\begin{abstract}
South Africa had anti-market abuse legislation in place since the late 1990s but nonetheless the enforcement of such legislation to combat market abuse activities has been inconsistent and problematic to date. The objective of this article is to provide an overview analysis of some factors that have to date contributed too many challenges that are associated with the inconsistent enforcement of the market abuse laws in South Africa. This is primarily done to increase awareness on the part of the general public, policy makers and other relevant stakeholders and to innovate possible solutions to such challenges in order to enhance the enforcement of the market abuse ban in South Africa. In relation to this, the article seeks to explore these enforcement problems by, first, taking a closer look at the effectiveness of the Financial Services Board (the FSB) as the market abuse national regulatory body in South Africa. Secondly, the co-operation between the FSB and other similar local and international enforcement bodies will be examined. Thirdly, the adequacy of the available resources, penalties and remedies will be discussed. Lastly, the adequacy of the market abuse preventative measures that were adopted in South Africa will be discussed.
\end{abstract}

Keywords: market abuse, market manipulation, insider trading, financial markets, enforcement.

\section{Introduction}

It is submitted that there is no comprehensive and satisfactory definition of "market abuse" that exist to date (Fischel \& Ross "Should the Law Prohibit 'Market Manipulation' in Financial Markets" 1991 Harvard Law Review 503506 \& Avgouleas The Mechanics and Regulation of Market Abuse: A legal and Economic Analysis (2005) 104). However, for the purposes of this article "market abuse" is used as a generic term referring to insider trading and market manipulation. South Africa had anti-market abuse legislation in place since the late 1990s but nonetheless the enforcement of such legislation to combat market abuse activities has been inconsistent and problematic to date (Jooste "A critique of the insider trading provisions of the 2004 Securities Services Act" 2006 SALJ 437 441-460; Osode "The new South African Insider Trading Act: Sound law reform or legislative overkill?" 2000 Journal of African Law 239 239; Van Deventer "New watchdog for insider trading" 1999 FSB Bulletin 2 3; the King Task Group into Insider Trading Legislation Minority Report on Insider Trading 1997 paragraph 3.4 as summarised in Beuthin \& Luiz Beuthin's Basic Company Law (2000) 235-238; also see generally Chitimira The Regulation of Insider Trading in South Africa: A Roadmap for an Effective, Competitive and Adequate Regulatory Statutory Framework (LLM dissertation, University of Fort Hare, 2008) 41-72). The objective of this article is to analyse and reveal that the enforcement of market abuse laws has been problematic in South Africa. (See Van Deventer "Anti-Market Abuse Legislation in South Africa" (10-06-2008) 1-5 <http://www.fsb.co.za/public Imarketabuse/FSBReport.pdf> (accessed 05-08-2013) \& Myburgh \& Davis "The Impact of South Africa's Insider Trading Regime: A Report for the Financial Services Board" (25-03-2004) 8-33<http://www.genesis-analytics.com/public IFSBReport.pdf> (accessed 09-07-2013). Also see Bhattacharya \& Daouk "The World Price of Insider Trading" 2002 Journal of Finance 75 75-108; Lyon \& Du Plessis The Law of Insider Trading in Australia (2005) 159-168 for further related comparative analysis). In this regard, the article provides an overview analysis of some factors that have to date contributed too many challenges that are associated with the inconsistent enforcement of the market abuse laws in South Africa. (Such factors include the inherent complexities and flaws in the detection, prosecution and prevention of market abuse practices in the South African financial markets). This is primarily done to increase awareness on the part of the general public, policy makers and other relevant stakeholders and to innovate possible solutions to such challenges in order to enhance the enforcement of the market abuse ban in South Africa. In relation to this, the article seeks to explore these enforcement problems by, first, taking a closer look at the effectiveness of the Financial Services Board (the FSB) 
as the market abuse national regulatory body in South Africa. Secondly, the co-operation between the FSB and other similar local and international enforcement bodies will be examined. Thirdly, the adequacy of the available resources, penalties and remedies will be discussed. Lastly, the adequacy of the market abuse preventative measures that were adopted in South Africa will be discussed.

\section{Adequacy and Efficiency of the National Regulator?}

The FSB was established in terms of the Financial Services Board Act (97 of 1990, hereinafter referred to as the Financial Services Board Act) as an independent board and a national regulator to police, supervise and enforce the market abuse ban in South Africa. (See s 84(1) of the Financial Markets Act 19 of 2012, hereinafter referred to as the Financial Markets Act, which came into effect on 03 June 2013. Notably, this provision is similar to s 82(1) of the Securities Services Act 36 of 2004, hereinafter referred to as the Securities Services Act, which has now been repealed and will only be referred to where necessary for historical comparative purposes since there are currently very few sources on the regulation of market abuse under the Financial Markets Act). The FSB has ostensibly wide powers to enhance and improve the enforcement of the market abuse prohibition in South Africa, (see s 84 of the Financial Markets Act). Significant progress in relation to the enforcement of the market abuse prohibition has been made since the inception of the FSB in 1999. For instance, the FSB is empowered to investigate all cases of suspected market abuse, including insider trading committed before the repeal of the Securities Services Act (see Chapter VIII) and the Insider Trading Act (135 of 1998, hereinafter referred to as the Insider Trading Act; Notably, in terms of the Financial Markets Act, s 84(2)(a), the FSB is no longer required to investigate insider trading offences committed before the repeal of $s$ 440F of the Companies Act 61 of 1973, hereinafter referred to as the Companies Act). All incidents of unusual trading patterns are brought to the attention of the FSB for further investigation. The FSB is further allowed to interrogate any persons believed to have information relating to an ongoing investigation (s 84(3)(b) of the Financial Markets Act; this provision re-duplicated s 82(2)(e) of the Securities Services Act), and search any person, premises or strongroom in order to seize any document suspected to have information relating to an ongoing investigation. (Section 84(3)(c) of the Financial Markets Act; this provision recycled s 82(2)(f) of the Securities Services Act without providing any useful changes). Although not many criminal prosecutions have been successfully obtained, the FSB has managed to investigate a fair number of suspected market abuse violations to date. (Generally see Myburgh \& Davis 28. Notwithstanding the fact that this Myburgh \& Davis report was published in 2004 before the Financial Markets Act came into effect and the fact that it was somewhat influenced by the opinions of the interviewees, it shall be referred to in this article where necessary, not as the only basis or evidence of the existence of market abuse activity in the South African financial markets but as a pointer on how market abuse laws were enforced in South Africa prior to the enactment of the Financial Markets Act. Moreover, the Myburgh \& Davis report and a few other selected and available reports and/or sources will be referred to throughout this article because there are currently very few new sources on the regulation and enforcement of the market abuse prohibition in South Africa, especially under the Financial Markets Act).

The FSB is entitled to take civil action against any person who contravenes the relevant provisions of the Financial Markets Act (s 82) and fails to rely on any of the defences set out in the same Act, (s 78). This civil liability applies only to matters relating to insider trading under the Financial Markets Act. No similar civil action could be instituted against the market manipulation offenders under the Financial Markets Act (ss 80 \& 81). (Unfortunately, this status quo was directly borrowed from the Securities Services Act, see ss 75 \& 76, without addressing the aforesaid flaw). This omission on the part of the legislature may, if not promptly addressed, affect the enforcement of the market abuse prohibition by the FSB. (R Cassim "An Analysis of Market Manipulation under the Securities Services Act 36 of 2004 (Part 2)" 2008 SA Merc LJ 177 192; 193; 198 \& 199). This flaw could have been corrected if the Financial Markets Act extended the civil liability, specific penalties and adequate defences to matters involving market manipulation. However, the penalty for actual profit or loss avoided in civil cases relating to insider trading is now determined by the Enforcement Committee (the EC) and not the FSB, (see s 82 of the Financial Markets Act; conspicuously, such penalty was expressly determined by the relevant courts under the Securities Services Act, s 77).

Moreover, no provision is expressly made for the aggrieved persons to institute their own statutory claims for damages (private rights of action, which are not necessarily common law damages), apart from the FSB, directly against the market abuse offenders. (S 82 read with s 87 of the Financial Markets Act; this provision re-introduced a similar flaw that was embedded in s 77 read with s 85 of the Securities Services Act). Notably, unlike in criminal cases where the prosecuting authorities have to prove the guilty of the accused beyond reasonable doubt, the FSB is only required to prove on a balance of probabilities that the defendant violated the relevant provisions of the Financial Markets Act in civil 
cases of market abuse. Accordingly, the FSB has to date relatively achieved some success in the enforcement of the civil sanctions of insider trading. For example, the FSB is believed to have utilised and obtained the following remedies in a number of instances:

(a) recovering the profit made or loss avoided by the offenders; awarding a penalty for compensatory and punitive purposes of up to three times the profit made or loss avoided; and

(b) recouping its legal and investigation costs from the money recovered and distributing the balance to compensate the victims (prejudiced investors) who can prove that they suffered loss as a result of the illegal dealing (insider trading) by the insider concerned. (It is stated that about 1218 claimants benefited from the distribution of the funds recovered by the FSB during the period from 17 January 1999 to 31 January 2005. See generally Van Deventer 1-5; the Directorate of Market Abuse Report Media Release $<$ http://www.fsb.co.za> (accessed 13-06-2013).

Nonetheless, although the FSB is reported to have sufficient sophisticated equipment in place and persons with the relevant expertise to detect market abuse and enforce the market abuse ban, a minimal number of successful prosecutions and settlements have been obtained in market abuse cases in South Africa to date, (see Cassim 192-196). On the other hand, a survey conducted by the Genesis Analytics (Pty) Ltd on behalf of the FSB to assess the impact of the insider trading laws revealed that market abuse activities especially insider trading, have been significantly reduced. (See Myburgh \& Davis 27-28). For example, about 80 per cent of the respondents reported that insider trading has become less acceptable, 77 per cent of the traders and asset managers viewed the insider trading laws as having been successful in reducing insider trading and 59 per cent of the listed companies interviewed had implemented insider trading policies and other measures to curb market abuse activity. (For further analysis see Myburgh \& Davis 17-20). The same survey indicated that 60 per cent of smaller retail brokerages did not have compliance manuals dealing with insider trading and only 20 per cent had some measures to deal with the protection and disclosure of inside information, (see Myburgh \& Davis 24-25). Furthermore, 18 per cent of the listed companies interviewed were reluctant to implement and comply with the insider trading laws and the relevant requirements of the FSB. (See Myburgh \& Davis 20). The FSB also stated in its 2005 Annual Report that although there was a steady decline in insider trading cases, insider trading and other market abuse practices had certainly not been completely eradicated.

It remains unclear whether the decline in reported cases is being caused by effective enforcement on the part of the FSB or whether it could be due to the fact that some market abuse activities are not being detected by the Johannesburg Stock Exchange Limited (the JSE) and/or the FSB. This survey further revealed that individuals who settled with the FSB were either guilty or probably guilty according to 80 per cent of the respondents. It also showed that the fine imposed was the most important reason for consideration when settling with the FSB, according to 4 per cent of the respondents. (See Myburgh \& Davis 15, for related comments). Other respondents were more concerned about how settling with the FSB would be perceived within the marketplace. For example, about 75 per cent of the respondents reported that they will consider the damage to their career, 12 per cent said that they will look at the shame of being caught, 4 per cent indicated that they would need to know if their names will be published in the press and 90 per cent of the respondents said their major concern would be the damage to the company's reputation. (See Myburgh \& Davis 16, for related comments). This implies that there is some stigma associated with settling with the FSB. The reason for this stigma could be three-fold. First, it may be because the FSB has managed to change the attitudes of all the relevant persons and market abuse activities are now less acceptable in the South African financial markets. Secondly, listed companies linked to market abuse settlements with the FSB have sometimes ended up being unsuccessful. (Myburgh \& Davis 17-18). Lastly, other affected persons may be having some doubts as to whether their cases will be successful or timeously settled. This could be due to the fact that only successful claimants will receive compensation after the FSB had recouped its legal and investigation costs from the money recovered from the offenders. (Perhaps, adequate provisions for private rights of action should be introduced to enable aggrieved persons to institute their own statutory claims for damages directly against the offenders).

\section{Co-operation and Adequacy of Resources?}

\subsection{Co-operation between the FSB and other Local Enforcement Agencies}

The FSB does not operate in a vacuum; it works in association with other enforcement bodies namely the JSE, the EC, the Directorate of Market Abuse (the DMA), the Board of Appeal (the BOA) and the courts. First, the FSB houses the DMA as its investigatory committee established in terms of the Financial Markets Act, (see s 85(1)(a) \& (b)). Duties and 
powers which the DMA may exercise on behalf of the FSB are clearly stipulated in the Financial Markets Act, (see $s$ 85(1)(c); nonetheless, this provision recycled s 83(1)(c) of the Securities Services Act without expanding the mandate and/or powers of the DMA). For example, the DMA may, on behalf of the FSB, decide whether to take a civil action or to refer a matter to the EC or the Director of Public Prosecutions. Notably, the DMA may only institute civil proceedings in the name of the FSB and may settle any matter after confirmation from the FSB (see s 85(1)(c) of the Financial Markets Act) or the competent courts. Accordingly, the mere fact that the DMA only exercises specific powers in the name of the FSB and does not function as an independent regulatory body (s 85(1)(d) of the Financial Markets Act, which merely resembles $s$ 83(1)(d) of the Securities Services Act) could be viewed as proof of an existing good co-operative relationship between the FSB and the DMA. (See generally Loubser "Insider Trading and other Market Abuses (Including the Effective Management of Price-sensitive Information)" in the Insider Trading Booklet final draft (02-10-2006) 26-27, $<$ http://www.jse.co.za/public/insider/JSEbooklet.pdf> (accessed 10-06-2013). Secondly, the FSB works closely with the $\mathrm{EC}$ as its committee responsible for adjudicating on all the market abuse cases referred to it by the DMA or the Registrar of Securities Services. (See s 99 of the Financial Markets Act). The EC is made up of members appointed by the FSB. (Luiz "Market Abuse and the Enforcement Committee" 2011 SA Merc LJ 151 156-159). Apart from being empowered to impose unlimited administrative penalties against the market abuse offenders, the EC is obliged to submit annual reports regarding its activities during the preceding calendar year to the FSB. This suggests that there is some co-operation between the FSB and the EC and, according to Gerhard van Deventer, (see Van Deventer 1-5), such co-operation has improved the enforcement of the market abuse prohibition in South Africa. Thirdly, there is co-operation between the FSB and the BOA. The BOA was first established in terms of the Financial Services Board Act (s 26) to hear and afford all the persons aggrieved with any decision of the executive officer of the FSB, the Registrar of Securities Services or the claims officer as contemplated in the Financial Markets Act (s 105), a chance to lodge their complaints for them to be addressed. (See ss 26A \& 26B of the Financial Services Laws General Amendment Act 22 of 2008). The BOA is an independent tribunal comprising members appointed by the Minister of Finance and who are neither employees of the FSB nor active participants in the financial industry. (See s 26A of the Financial Services Board Act). The FSB is reportedly co-operating with the BOA in a number of ways, such as providing oral and/or written evidence or any other relevant information required by the BOA. In order not to interfere with the proceedings of the BOA, the FSB directs all queries relating to an appeal by the aggrieved persons to the secretaries of the BOA. Nonetheless, the consistency on the part of the FSB, to comply with the requests from the BOA remains uncertain. (In other words, the actual extent or degree of co-operation between the FSB and the BOA is not very clear).

Fourthly, the FSB enjoys much support from the JSE and it depends on the JSE's Surveillance Division to detect market abuse practices in the South African financial markets. (For further related discussion, see Loubser op cit at 25; Myburgh \& Davis 12-13). The JSE further requires all the issuers of listed securities to disclose any activities that might have a material effect on the price of such securities, (s 3.4 of the JSE Listing Requirements). When an unusual trading activity is detected by the JSE's Surveillance Division, it is reported to the FSB for further investigation. It is reported that a number of market abuse investigations have in fact been carried out by the FSB on the advice of the JSE's Surveillance Division. (See Myburgh \& Davis op cit at 28, who outlines the role played by the JSE, especially, in relation to the curbing of insider trading activities prior to 2004). The FSB and the JSE have further co-operatively played a key role in educating all the relevant persons about market abuse practices through seminars and workshops in South Africa. Moreover, the FSB also used to rely on the Bond Exchange of South Africa (the BESA), before the latter was consolidated into the JSE, to detect market abuse activity in relation to the commodities, bonds and derivatives markets in South Africa. (The aforesaid formal consolidation was finalised on 22 June 2009 \& the BESA is now a fully owned subsidiary of the JSE). However, the BESA was reportedly not playing an active role in the surveillance of market abuse practices and in assisting the FSB to enforce the market abuse ban in the South African commodities, bonds and derivatives markets. (See Myburgh \& Davis 13). It remains to be seen whether the aforesaid consolidation will enhance the co-operation and effectiveness of the enforcement of the market abuse prohibition in South Africa by both the FSB and the JSE. Fifthly, the Law Society of South Africa and the Securities Regulation Panel offers further support to the FSB. According to Gerhard van Deventer, (see generally Van Deventer 1-5), the FSB has good co-operation with these bodies and has, in some instances, utilised their advice to combat certain market abuse activities in the South African financial markets. Lastly, the FSB may rely on the courts. Irrespective of the fact that the competent courts (s 84(4)(b) \& (10) of the Financial Markets Act) are empowered to hear market abuse cases referred to them by the FSB, some cases have been either withdrawn or abandoned by the courts. This might imply that there is little or no co-operation between the FSB and the courts. 


\subsection{Co-operation between the FSB and Listed Companies}

A Genesis Analytics (Pty) Ltd (Myburgh \& Davis 19) survey revealed that about 72 per cent of the listed companies had internal policies aimed at discouraging market abuse practices. About 18 per cent of the listed companies were cooperating with the FSB by implementing such policies to reduce market abuse practices in South Africa. (See Myburgh \& Davis 20). Most of the listed companies that implemented anti-market abuse policies were, among others, asset managers, investment banking and corporate finance companies. (Myburgh \& Davis 23-24). The companies that failed to comply with the FSB's market abuse policies and requirements were mainly retail brokerages companies and other smaller companies. (Myburgh \& Davis 24-25; this could also suggest that some unlisted companies did not comply with the FSB's anti-market abuse policies). Furthermore, there have been very few or no incidents where the employees of the listed companies reported other persons involved or who might be involved in market abuse activities in their companies (whistle-blowing) to the FSB, (it is hoped that the FSB will, in the future, employ bounty rewards and/or incentives to encourage more co-operation with all the relevant stakeholders). It is further hoped that the co-operation between the FSB and both the listed and unlisted companies will continue to be encouraged to enhance the enforcement of the market abuse ban in South Africa.

\subsection{Co-operation between the FSB and similar International Enforcement Agencies}

Owing to the increasingly global nature of trading in listed instruments, the FSB has reportedly entered into some cooperation agreements with similar bodies elsewhere in the world, such as the Financial Services Authority (the FSA) and the United States Securities and Exchange Commission (the SEC). (See Loubser 26). The rationale behind these agreements is inter alia, to curb as much as possible all cross-border market abuse activities in the financial markets. For instance, these co-operation agreements allow the FSB to track the activities of market abuse suspects who use other jurisdictions to contravene the South African market abuse laws, hoping to evade and escape liability. (See Loubser 26). It is further reported that the FSB has, in some instances, relied on its FSA and SEC co-operative agreements and the Multilateral Memorandum of Understanding it has with regulatory bodies in other jurisdictions (for example, the Securities and Exchange Board of India \& the International Organisation of Securities Commissions) to extra-territorially detect cross-border market abuse activities in South Africa and elsewhere. However, the FSB does not seem to have its own sufficient additional resources and measures in place to enable it to co-operate more with similar bodies at an international level. (Generally see Loubser 26). In this regard, the FSB should continue striving to employ other relevant regulatory approaches from other jurisdictions to enable greater awareness of any enforcement changes that might occur in such jurisdictions and to develop trust and better communication with similar regulatory bodies, especially from the developed world. (See Chitimira \& Lawack "An Analysis of the General Enforcement Approaches to Combat Market Abuse (Part 1)" 2012 Obiter 548 549-565; Chitimira \& Lawack "An Analysis of the General Enforcement Approaches to Combat Market Abuse (Part 2)" 2013 Obiter 64 65-76, for further analysis on enforcement approaches).

\subsection{Adequacy of Available Resources}

There has been a growing recognition in recent years of the fact that having adequate market abuse laws alone is not sufficient; instead enforcement authorities should have the relevant resources and other appropriate measures in place in order to effectively enforce such laws to combat market abuse practices. (See Bhattacharya \& Daouk 75-108; Myburgh \& Davis 8-33; Lyon \& Du Plessis 159-168 \& see further Beny "Insider Trading Laws and Stock Markets Around the World: An Empirical Contribution to the Theoretical Law and Economics Debate" (2006) John M Olin Center for Law and Economics University of Michigan Law School 35-41 <http://www.law.umich.edu/centersandprograms/olin/papers.htm> (accessed 01-09-2012), for an additional general comparative analysis on the enforcement of insider trading laws in different jurisdictions). The enforcement authorities in many jurisdictions have resources like surveillance technology and equipment to detect market abuse activity in the financial markets. Additionally, other enforcement authorities have the much-needed financial resources to train their workers, recruit persons with the relevant expertise and employ the necessary methods to ensure compliance with, and proper enforcement of the market abuse laws in their respective jurisdictions. Likewise, in South Africa, the FSB is reported to have sophisticated machinery in place and competent persons to detect and enforce the market abuse prohibition. (See Van Deventer 1-5; Loubser 26-27). The FSB does not rely on the government's subsidies per se; it finances its operations by recouping all the legal and investigation costs it would have incurred from the money recovered from the market abuse offenders. (See ss 82(4)(a) \& 86 of the Financial 
Markets Act, which simply resembles ss 77(7)(a) \& 84 of the Securities Services Act without introducing other alternative measures on the financing of the FSB and/or the DMA). However, the FSB does not have, and is still to mobilise sufficient additional resources for the procurement and establishment of its own its own surveillance systems to detect possible market abuse practices in the South African financial markets so that its enforcement efforts may not be hampered by bureaucracy.

\section{Complexities and Flaws in the Detection and Prosecution}

\subsection{Frequent Occurrence of Market Abuse Activity Extremely Difficult to Prove}

In the last few years, there has been a decline in the number of prosecutions and reported cases of insider trading and market manipulation in South Africa. (See Myburgh \& Davis 30). The prima facie explanation for this reduction in reported cases and prosecutions may be that there are now very few or no market abuse activities occurring in South Africa. However, the research interviews conducted by Genesis Analytics (Pty) Ltd with traders and asset managers, market advisors, company secretaries of listed companies and financial compliance officers indicated that, although the extent could not be accurately quantified, market abuse activities were still occurring with some frequency in the South African financial markets. (Myburgh \& Davis 27-30). Nevertheless, these research findings could be criticised in that they were more influenced by opinions and as a result, they lacked a strong accurate basis of empirical data regarding the frequency or degree of occurrence of market abuse activity in the South African financial markets. Be that as it may, the author maintain that the aforesaid research findings could be employed because they usefully expose the inherent challenges involving the prosecution and/or detection of market abuse practices in South Africa. (See related discussion that will ensue under sub-headings below). It is submitted that despite the lack of accurate empirical data quantifying the occurrence of market abuse activity in South Africa, there is some anecdotal evidence indicating that market abuse practices have not been completely eradicated from the South African financial markets. (See Myburgh \& Davis 30). Therefore, the significant reduction in reported cases and prosecutions could be caused by the fact that the occurrence of market abuse activity is extremely difficult to prove and/or some instances of such activity may be going unnoticed.

\subsection{Market Abuse Activity Extremely Difficult to Detect}

In spite of the fact that the FSB is generally believed to have adequate resources and skilled persons to enforce the market abuse prohibition, there are still some shortcomings in the detection of the market abuse activity in the South African financial markets. At a glance, one could conclude that the reason underpinning such shortcomings is the inefficiency of the FSB. (See earlier sub-headings above). Furthermore, some procedures adopted by the FSB may be criticised to some extent for being bureaucratic because it may only detect possible market abuse activity after alerts of suspicious trading patterns from the JSE's Surveillance Division. However, notwithstanding these flaws, other commentators have submitted that market abuse practices are extremely difficult to detect for the regulatory bodies globally. (See generally Gething "Insider Trading Enforcement: Where are We Now and Where do We Go from Here?" 1998 Company and Securities Law Journal 607 618; Lyon \& Du Plessis 163-166). The difficulty is sometimes experienced in detecting the identity of the actual perpetrators and thereafter proving their connection to any information relating to the alleged market abuse activity timeously. The need to distinguish illegal dealing from bona fide dealing done by insiders on behalf of their companies poses further obstacles to the successful detection of market abuse activity in the financial markets. However, one can still conclude that the difficulty in detecting the identity of the perpetrators in matters involving insider trading should be ameliorated because insider trading is usually done by directors or other employees who trade in the securities of their own companies or of the companies with whom they have dealings, for example during takeover negotiations. (See Tomasic \& Pentony "Coming Down on Insiders: Why we Have to Curb the Casino Operators" 1989 Journal of the Australian Society of Securities Analysts 24 26; Tomasic \& Pentony "Crime and Opportunity in the Securities Markets: The Case of Insider Trading in Australia" 1989 Company and Securities Law Journal 186 196-198). In South Africa, these challenges could have been worsened by the fact that the FSB does not seem to be using other detection strategies like engaging more brokerages and companies that digitally record telephonic transactions from clients to their agencies, bounty rewards and whistle-blowing immunity to timeously combat market abuse violations. 


\subsection{Market Manipulation and Insider Trading cases Inherently Difficult to Prosecute}

Notwithstanding the fact that much ground has been covered with regard to the enforcement of the market abuse ban, some loop-holes are still found, especially in the prosecution of market abuse cases in South Africa. The FSB may only prosecute criminal cases of market abuse if the Director of Public Prosecutions neglects to prosecute them. (See $\mathrm{S}$ 84(10) of the Financial Markets Act; this provision resembles s 82(9) of the Securities Services Act). This clearly shows that, unless if a matter is settled out of the courts, only the Director of Public Prosecutions has the prerogative to prosecute any market abuse cases referred to it by the FSB. Nonetheless, a minimum number of market abuse cases have been successfully prosecuted by the courts to date. (Only 32 cases of insider trading, eight cases of trade-based market manipulation and no cases for disclosure-based market manipulation were reportedly investigated by the FSB during the period between January 1999 and January 2008. No convictions were obtained by the courts in all the criminal cases of market abuse. This information was obtained from an interview that was conducted at the FSB by the author with Mr Gerhard van Deventer "the Executive Director of the DMA" on 05 May 2009). This could have been caused by the fact that market abuse cases are reportedly difficult to prosecute. (Chanetsa "Insider Trading is Notoriously Hard to Prosecute" Business Report 26 April 2004). Another reason could be the complexities involving the burden of proof required beyond reasonable doubt in criminal cases of market abuse. Notably, the burden of proof required in civil cases is for the defendant to prove, on a balance of probabilities, that he did not commit the market abuse practice in question. (See s 82 of the Financial Markets Act). As a result, the FSB has managed to obtain a fair number of settlements in civil cases of market abuse because the standard of proof required of the balance of probabilities is generally lower and more flexible. (Generally see Myburgh \& Davis 12). The reason for the low number of civil cases of market abuse that have been successfully settled in South Africa could be that the required burden of proof of the balance of probabilities might be inconsistently applied. (Luiz "Market Abuse II-Prohibited Trading Practices and Enforcement" 2002 Juta's Business Law 180 181-183). On the other hand, it is onerous on the part of the prosecuting authorities to prove beyond reasonable doubt that the accused person knowingly committed the market abuse offence in question. (See Luiz 182183). Furthermore, the backlog associated with the competent courts could have caused other criminal cases of market abuse to be delayed, withdrawn or abandoned.

\subsection{Enforcement of Market Manipulation and Insider Trading Prohibition Treated Separately and Differently}

Another challenge associated with the enforcement of the market abuse prohibition in South Africa is the fact that insider trading and market manipulation offences are inconsistently defined and treated separately and differently. (Luiz 183). As discussed earlier, the FSB does not impose a derivative civil action against market manipulation offenders. (Cassim 192). Furthermore, although administrative sanctions may be imposed on all the forms of market abuse, the EC may statutorily impose on behalf of the victims a compensatory fine only in matters involving insider trading. (Cassim 195; Luiz 183). Seemingly, the Financial Markets Act (ss 80 \& 81) treats market manipulation only as a criminal offence. (This flaw was recycled from the Securities Services Act and has remained unresolved, see Cassim 191-193 \& 199). Moreover, the concepts of insider trading and market manipulation are both not expressly defined in the Financial Markets Act. (Only a few terms like "market abuse rules" and "market corner" are expressly defined in the Financial Markets Act; ironically, this flaw was also borrowed from the Securities Services Act, see Chapter VIII). Some key terms relating to market manipulation such as "market manipulation", "market participant" and "making" or "publication" of "deceptive statements" are not expressly defined in the Financial Markets Act, (see s 77 read with ss 80 \& 81). (This flaw was borrowed from the Securities Services Act, see s 72 read with ss $75 \& 76$ and has remained uncorrected). Additionally, unlike in cases relating to insider trading, not many defences are provided for market manipulation. (Cassim 183). Only a pricestabilisation defence is provided in the Financial Markets Act (s 80). (Ironically, this shortcoming was also copied from the Securities Services Act, see s 75). In this regard, the author concur with Cassim (Cassim 199) that the policy makers did not provide other additional defences for market manipulation, for example Chinese walls or the defence that the accused person believed on reasonable grounds that his behaviour did not amount to market manipulation so as not to discourage legitimate trading and to avoid unfair convictions of innocent accused persons. (See Cassim 183-191; ss 80 $\& 81$ of the Financial Markets Act).

\subsection{Adequacy of Available Penalties and Remedies}

Although there may be a general assumption that there is no amount of penalties that can stop the occurrence of market 
abuse in the global financial markets, it is submitted that Cassim (Cassim 191-195) correctly argues that the stipulated market abuse penalties and remedies somehow fall short when it comes to deterrence purposes, (see s 109(a)) of the Financial Markets Act; conspicuously, this flaw was previously embedded in s 115(a) of the Securities Services Act and has not been addressed to date). Criminal penalties can be imposed on all the forms of market abuse in South Africa. Moreover, all the persons who contravene the relevant market abuse provisions may be sentenced to a fine not exceeding R50 million or imprisonment for a period not exceeding 10 years or both such fine and imprisonment. (See $\mathrm{s}$ 109(a) of the Financial Markets Act). With regard to insider trading, the accused persons would only incur criminal liability if they fail to rely on any of the defences provided in the Financial Markets Act. On the other hand, a statutory civil remedy is only available to matters involving insider trading. (Cassim 193). While the market abuse criminal sanctions of a R50 million maximum fine and imprisonment for a period not exceeding 10 years may be fairly dissuasive, it is submitted that reliance on these sanctions alone cannot be an effective deterrent. (Section 109(a) of the Financial Markets Act; see further Cassim 194 \& Chitimira \& Lawack 549-553). A criminal remedy alone may give rise to a few convictions to be obtained in market abuse cases because the criminal standard of proof beyond reasonable doubt is difficult to meet compared to the relatively lighter civil standard of proof on a balance of probabilities. (Cassim 193; Chitimira \& Lawack 549-555). Apart from the criminal and civil penalties, the Financial Markets Act provides unlimited administrative penalties for all the forms of market abuse. However, the EC may impose on the offenders a compensatory amount payable to the FSB only in matters relating to insider trading. (See generally s 99 of the Financial Markets Act; Cassim 195). This disparity and the fact that the EC may only impose administrative penalties on a referral basis could affect the effectiveness of administrative sanctions in South Africa. Other measures such as imposing a separate maximum criminal penalty on individuals and juristic persons, with a much higher maximum penalty to be imposed on such juristic persons are not statutorily provided. (See s 109(a) of the Financial Markets Act; Cassim 194). Unlike the FSA (see s 123(1) of the Financial Services and Markets Act 2000 (c 8), hereinafter referred to as the Financial Services and Markets Act), the FSB and other enforcement authorities may only impose a limited number of criminal penalties against the market abuse offenders. (Section 109(a) of the Financial Markets Act; see further Cassim 194).

\subsection{Awareness of Market Abuse Practices?}

Market abuse activities are very difficult to detect directly. As a result, many victims seldom know that market abuse activities are illegal or when they have been prejudiced by such activities. It is generally submitted that the enforcement of the market abuse prohibition has not been very successful in South Africa, partly because some small companies and other relevant persons are still unaware of the nature and effects of market abuse. (Generally see Myburgh \& Davis 2426). According to a Genesis Analytics (Pty) Ltd survey, the FSB and the JSE have played an important role in educating all the relevant persons about the pervasiveness of market abuse since 1999. (Generally see Myburgh \& Davis 13). For example, both the FSB and the JSE have conducted some market abuse awareness presentations to the market participants and in 2002 the JSE published the Insider Trading Booklet to provide a guide on matters involving insider trading to all the relevant stakeholders. The same survey also indicated that some persons in the work places were fairly aware of market abuse practices, especially insider trading according to 93 per cent of the respondents. (Myburgh \& Davis 25). About 88 per cent of the market advisors and 89 per cent of the company secretaries' associates interviewed submitted that the awareness of insider trading laws had increased significantly in the South Africa. (Myburgh \& Davis 25). The JSE's Insider Trading Booklet was read by 54 per cent of the respondents and 42 per cent of the respondents had attended a presentation by either the FSB or the JSE. (Myburgh \& Davis 26). The JSE's Insider Trading Booklet was used by 27 per cent of the listed companies to educate their employees while 53 per cent of such companies derived their own internal regulatory rules from it between 1999 and 2004. (Myburgh \& Davis 26). However, very few or no measures were employed by the FSB and the JSE to provide awareness regarding market manipulation. Moreover, the FSB does not employ a more expansive awareness strategy, involving the posting of comprehensive market abuse news on the Internet and the establishment of other divisions of its departments in all the provinces of South Africa. Additionally, there is no specific market abuse curriculum taught in schools and universities or a provision which expressly provides for extensive education on market abuse from grassroots level in order to increase compliance by changing the illicit norms and attitudes among some market participants in South Africa. The same shortcoming was not resolved in the Financial Markets Act (see ss 78; 80; 81 \& 82). 


\subsection{Development of Anti-Market Abuse Culture?}

Although several measures aimed at combating market abuse, like the enactment of market abuse laws, were introduced in South Africa, market abuse activity has not been completely eradicated in the South African financial markets to date. This could raise some questions in the minds of potential investors as to whether the FSB has done enough to develop strong anti-market abuse norms and attitudes among all the relevant stakeholders in South Africa. A Genesis Analytics (Pty) Ltd survey indicated that insider trading was more socially acceptable until the late 1990s. According to 90 per cent of the market participants who were interviewed, the attitudes across the South African financial markets had changed and insider trading was now less acceptable, especially after 1999. (Myburgh \& Davis 16-17). Nonetheless, the FSB and lawyers advising the accused persons asserted that these accused persons were far less willing to settle their market abuse cases with the FSB. (See related remarks under the second sub-heading above). Furthermore, 71 per cent of the respondents submitted that insider trading laws and other anti-market abuse measures had changed the attitudes of the market participants in the South African financial markets to a fair extent. (Myburgh \& Davis 17). However, a significant minority of 22 per cent of the respondents reported that insider trading was still acceptable in South Africa and only 72 per cent of the companies had some internal anti-market abuse policies to discourage their employees from indulging in market abuse activities. (Myburgh \& Davis 19; 13-14). While these efforts could be welcomed as a positive attempt to develop a strong anti-market abuse culture, the legislature, the FSB and the JSE did not adopt a holistic approach because they gave more attention only to insider trading at the expense of other illicit practices like market manipulation. Moreover, other enforcement approaches like incentives, bounty rewards, unlimited criminal penalties and whistleblower immunity are not used to combat market abuse in South Africa. (Chitimira \& Lawack 72-74).

\section{Adequacy of Preventative Measures?}

The regulatory bodies globally must be statutorily empowered to have sufficient preventative measures in place to combat market abuse. These preventative measures should be adequately defined in order for them to be properly enforced. A Genesis Analytics (Pty) Ltd survey revealed that very few companies had internal policies to prevent market abuse. Only 72 per cent of the larger companies had some policies to prevent insider trading while smaller companies with fewer than 5000 employees did not have such policies. (See Myburgh \& Davis 19-20; Ojah, Muhanji \& A Myburg "Market Reaction and Equity Market Efficiency: A Survey of the Insider Trading Law in South Africa" 2008 The African Finance Journal 19 ). Moreover, only 58 per cent of the companies had some systems aimed at stopping all their insiders, especially senior employees like directors, from trading in the company's shares without permission and when a cautionary announcement was made, (ibid). According to other respondents, 35 per cent of the companies required their senior employees and/or all the employees to get written permission to trade in the company's shares, (ibid). About 96 per cent of the companies had rules to control the flow of inside information by imposing restrictions on who among their employees was allowed to speak to financial analysts. Nevertheless, 50 per cent of the companies interviewed did not take any record of the conversations between their employees and the financial analysts. (Myburgh \& Davis 21). Only 75 per cent of the companies were in compliance with the JSE's rules requiring any leaked inside information during a company's annual general meetings to be timeously communicated to the financial markets through the JSE's Securities Exchange News Service, (ibid). However, only 67 per cent of the institutional financial companies had compliance manuals and 80 per cent of these companies obliged their employees to sign them before making any transaction while 90 per cent had a restricted blacklist of shares or Chinese walls.

As highlighted above, it is clear that some companies had internal systems in place that were not mainly targeted at preventing market manipulation. Moreover, apart from relying on its powers to make market abuse rules (s $84(2)(\mathrm{f})$ of the Financial Markets Act) and the JSE's Surveillance Division to detect market abuse, the FSB is still to consistently employ other preventative methods like public censure (s 84(2)(e) of the Financial Markets Act) to discourage market abuse practices in South Africa. This could give rise to non-compliance on the part of the market participants and other relevant stakeholders. For example, not all listed companies timeously comply with the JSE Listing Requirements (s 3.4) which require all companies to enter into confidentially agreements with service providers like printing companies to prevent market abuse activities. Additionally, the Financial Markets Act (see ss 78; 80; 81; 82; 84; 85 \& 109(a)), does not have specific provisions for other market abuse preventative measures like:

(a) the use of Chinese walls between the company's trading divisions and the non-trading divisions; trading restrictions on the company itself, company directors and shareholders;

(b) more stringent methods that will force all companies, especially listed companies, to have internal codes of 
conduct and procedures that will stop their employees from committing market abuse offences; unlimited criminal penalties for market abuse offences; and a prohibition on the illicit disclosure of price-sensitive information on the Internet to prevent the illegal use of inside information since the Internet is one of the main conduits of much information globally. (Cassim 182).

\section{Concluding Remarks}

Although South Africa, like several other countries, has made numerous efforts to combat market abuse practices, a lot may still need to be done to eradicate the negative effects caused by such practices in the South African financial markets. (Cassim "An Analysis of Market Manipulation under the Securities Services Act 36 of 2004 (Part 1)" 2008 SA Merc LJ 33 33-36). Significant progress has been made with regard to the co-operation between the FSB and other local enforcement bodies like the JSE. Nevertheless, the same cannot be said regarding the co-operation of the FSB with listed companies and similar international regulatory bodies. Moreover, as earlier stated, the FSB does not employ private rights of action for the prejudiced persons and other anti-market abuse enforcement measures such as arbitration and alternative dispute resolution, bounty rewards and whistle-blowing immunity. Furthermore, although the JSE was rated as the number one stock exchange by the World Federation of Exchanges with regard to regulation in 2010 (National Treasury "Reviewing the Regulation of Financial Markets in South Africa: Policy Document Explaining the Financial Markets Bill 2011" August 2011 5), some flaws in the enforcement of the market abuse prohibition could have, to some extent, contributed to poor reputation to be associated with some South African companies. Given this background, it is recommended that the JSE and the FSB should consider employing practically applicable anti-market abuse proposals from other jurisdictions such as the back testing process, real-time risk monitoring and market surveillance measures. In light of this, it is submitted that the policy makers should consider introducing a specific provision into the Financial Markets Act that obliges and empowers the JSE's Surveillance Division to prosecute or report incidences of market abuse to the FSB. Another option is to financially and statutorily empower the FSB to procure its own market abuse surveillance systems and transfer the entire financial markets anti-market abuse surveillance responsibility from the JSE to the FSB. Furthermore, the legislature, the FSB and the JSE should consider adopting a holistic approach with regard to the development of a strong anti-market abuse culture and other preventative methods in South Africa. (Perhaps, the Financial Markets Act could be amended to enact provisions for other anti-market abuse measures such as whistle-blowing, class actions, private rights of action and bounty rewards). It is also hoped, given the everlasting backlog in our criminal courts, that additional specialised market abuse courts or tribunals and self-regulatory organs will be establishment in the future to complement the enforcement efforts of the FSB and enhance the criminal prosecution of market abuse cases in South Africa. In a nutshell, the article has revealed that the enforcement of the market abuse prohibition has remained problematic in South Africa to date. The article has also exposed that certain flaws previously embedded in the Securities Services Act's market abuse provisions were recycled and re-incorporated into the Financial Markets Act's market abuse provisions. In this regard, it is hoped that the recommendations as enumerated in this article will be utilised by the relevant stakeholders in the future to combat market abuse.

\section{References}

\section{Books}

Avgouleas E The Mechanics and Regulation of Market Abuse: A legal and Economic Analysis (Oxford University Press Oxford 2005) Benade ML et al Entrepreneurial Law $3^{\text {rd }}$ ed (Lexis Nexis Butterworths Durban 2003)

Beuthin RC and Luiz SM Beuthin`s Basic Company Law 3rd ed (Butterworths Durban 2000)

Lyon GJ \& Du Plessis JJ The Law of Insider Trading in Australia (The Federation Press Sydney 2005)

Milne A et al Henochsberg on the Companies Act $3^{\text {rd }}$ ed (Butterworths Durban 1975)

\section{Journal articles}

Bhana N "Take-Over Announcements and Insider Trading Activity on the Johannesburg Stock Exchange" 1987 South African Journal of Business Management 198-208

Bhattacharya U \& Daouk H "The World Price of Insider Trading" 2002 Journal of Finance 75-108

Botha D "Control of Insider Trading in South Africa: A Comparative Analysis" 1991 SA Merc LJ 1-18

Botha D "Increased Maximum Fine for Insider Trading: A Realistic and Effective Deterrent?" 1990 SALJ 504-508 
Cassim R "An Analysis of Market Manipulation under the Securities Services Act 36 of 2004 (Part 1)" 2008 SA Merc LJ 33-60 Cassim "An Analysis of Market Manipulation under the Securities Services Act 36 of 2004 (Part 2)" 2008 SA Merc LJ 177-199 Chitimira H \& Lawack VA "An Analysis of the General Enforcement Approaches to Combat Market Abuse (Part 1)" 2012 Obiter 548-565 Chitimira H \& Lawack VA "An Analysis of the General Enforcement Approaches to Combat Market Abuse (Part 2)" 2013 Obiter 64-76 Fischel DR and Ross DJ "Should the Law Prohibit 'Market Manipulation' in Financial Markets" 1991 Harvard Law Review 503-553

Gething M "Insider Trading Enforcement: Where are We Now and Where do We Go from Here?" 1998 Company and Securities Law Journal 607-627

Henning JJ and Du Toit S "The Regulation of False Trading, Market Manipulation and Insider Trading" 2000 Journal for Juridical Science 155-165

Jooste R "A critique of the insider trading provisions of the 2004 Securities Services Act" 2006 SALJ 437-460

Jooste R "Insider Trading: A New Clamp-Down" 1991 BML 248-250

Jooste R "Insider Dealing in South Africa-The Criminal Aspects" 1990 De Ratione 21-28

Kaufmann C \& Weber RH "The Role of Transparency in Financial Regulation" 2010 Journal of International Economic Law 779-797

Luiz SM "Market Abuse II-Prohibited Trading Practices and Enforcement" 2002 Juta's Business Law 180-183

Luiz SM "Prohibition Against Trading on Inside Information-The Saga Continues" 1990 SA Merc LJ 328-332

Luiz SM "Insider Trading Regulation - If at First You Don't Succeed..." 1999 SA Merc LJ 136-151

Luiz SM "Market Abuse and the Enforcement Committee" 2011 SA Merc LJ 151-172

Ojah K, Muhanji S \& Myburg A "Market Reaction and Equity Market Efficiency: A Survey of the Insider Trading Law in South Africa" 2008 The African Finance Journal 1-28

Osode PC "The new South African Insider Trading Act: Sound law reform or legislative overkill?" 2000 Journal of African Law 239-263

Osode PC "The Regulation of Insider Trading in South Africa: A Public Choice Perspective" 1999 African Journal of International and Comparative Law 688-708

Tomasic R \& Pentony B "Coming Down on Insiders: Why we Have to Curb the Casino Operators" 198924 Journal of the Australian Society of Securities Analysts 24

Tomasic R \& Pentony B "Crime and Opportunity in the Securities Markets: The Case of Insider Trading in Australia" 1989 Company and Securities Law Journal 186-198

Van der Lingen B "Tougher Legislation to Combat Insider Trading" 1997 FSB Bulletin 10

Van Deventer G "New watchdog for insider trading" 1999 FSB Bulletin 2-3

Van Zyl FH "Aspekte van Beleggersbeskerming in die Suid-Afrikaanse Reg" 1992 Transactions of the Center for Business Law 231-357

\section{Case law}

Pretorius and Another v Natal South Sea Investment Trust 19653 SA 410 (W)

Legislation

South Africa

Companies Act 71 of 2008

Companies Act 61 of 1973

Financial Advisory and Intermediary Services Act 37 of 2002

Financial Markets Act 19 of 2012

Financial Services Board Act 97 of 1990

Financial Services Laws General Amendment Act 22 of 2008

Insider Trading Act 135 of 1998

Securities Services Act 36 of 2004

\section{United Kingdom}

Financial Services and Markets Act 2000 (c 8)

Bills

\section{South Africa}

Financial Markets Bill B-2011

Financial Markets Bill B12-2012 


\section{Thesis and dissertations}

Chitimira H A Comparative Analysis of the Enforcement of Market Abuse Provisions (LLD-thesis Nelson Mandela Metropolitan University 2012)

Chitimira H The Regulation of Insider Trading in South Africa: A Roadmap for an Effective, Competitive and Adequate Regulatory Statutory Framework (LLM-dissertation University of Fort Hare 2008)

\section{Commissions, Reports and other Relevant Material}

\section{South Africa}

The King Task Group into Insider Trading Legislation Minority Report on Insider Trading 1997

The King Task Group into the Insider Trading Legislation First Report 15 May 1997

The King Task Group into the Insider Trading Legislation Final Report 21 October 1997

Van Wyk de Vries Commission of Inquiry into the Companies Act of 1973

\section{Newspaper reports}

Chanetsa B "Insider Trading is Notoriously Hard to Prosecute" Business Report 26 April 2004

\section{Internet sources}

Beny LN "Insider Trading Laws and Stock Markets Around the World: An Empirical Contribution to the Theoretical Law and Economics Debate" (2006) John M Olin Center for Law and Economics University of Michigan Law School <http://www.law.umich.edu/ centersandprograms/olin/papers.htm> (accessed 01-09-2012)

International Organisation of Securities Commissions Task Force on Unregulated Financial Markets and Products Technical Committee Unregulated Financial Markets and Products Final Report September $2009<$ http://www.iosco.org/library/pbdocs /pdf/IOSCOPD301.pdf> (accessed 07-07-2013)

JSE Listing Requirements <http://www.jse.co.za> (accessed 13 October 2013)

Loubser R "Insider Trading and other Market Abuses (Including the Effective Management of Price-sensitive Information)" in the Insider Trading Booklet final draft (02-10-2006), <http://www.jse.co.za/public/insider/JSEbooklet.pdf> (accessed 10-06-2013)

Myburgh A \& Davis B "The Impact of South Africa's Insider Trading Regime: A Report for the Financial Services Board" (25-03-2004) $<$ http://www.genesis-analytics.com/public/FSBReport.pdf> (accessed 09-07-2013)

Van Deventer G "Anti-Market Abuse Legislation in South Africa" (10-06-2008) <http://www.fsb.co.za/public/marketabuse /FSBReport.pdf> (accessed 05-08-2013) 